Antarctica

- Closing Statement of the 7th Summit of Non-aligned Nations at New Delhi

- Antarctic Mineral Resources

- Antarctic Mineral Resources Regime: Draft Articles

Germany, Federal Republic

- Convention on the Prohibition of Military or Any Other Hostile Use of Environmental Modification Techniques

- International Conference 1984 (Memorandum)
WEU

- Draft Recommendation on the Law of the Sea 81

54 - Law of the Sea (Resolution) 81

48 European Regional/Spatial Planning Charter 82

Islamic Principles for the Conservation of the Natural Environment 83

$\begin{array}{ll}\text { Inuit Circumpolar Conference: Resolutions } & 113\end{array}$

54

116

\title{
AUTHOR INDEX OF VOLUME 11
}

Heimsoeth, Harald, 59

Kwiatkowski, Barbara, 98

Muslim, Farouk, 69
Schröder, Meinhard, 64

Vygen, Hendrik, 34

Wetstone, Gregory, 26, 31 